\title{
Fulminant viral hepatitis
}

INSERM

\section{Source}

INSERM. (1999). Orphanet: an online rare disease and orphan drug data base. Fulminant viral hepatitis. ORPHA:35063

Fulminant viral hepatitis is a rapid and severe impairment of liver functions (acute liver failure) with hepatic encephalopathy developing less than 8 weeks after the onset of jaundice, secondary to viral hepatitis mainly due to HBV, but also to HAV. 